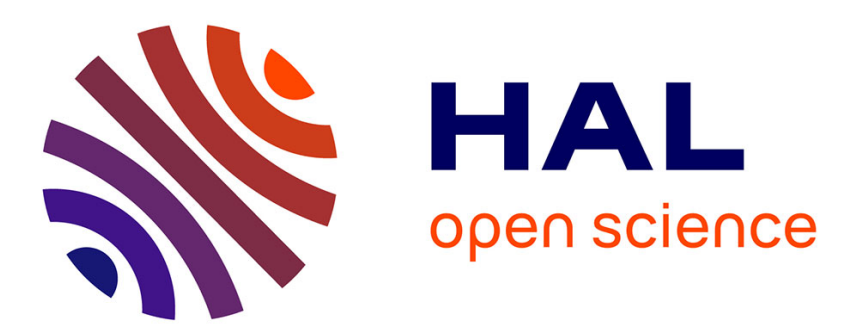

\title{
A framework to study strategizing activities at the field level: The example of CSR rating agencies
}

\author{
Tamim Elbasha, Emma Avetisyan
}

\section{To cite this version:}

Tamim Elbasha, Emma Avetisyan. A framework to study strategizing activities at the field level: The example of CSR rating agencies. European Management Journal, 2018, 36 (1), pp.38 - 46. 10.1016/j.emj.2017.02.001 . hal-01738328

\section{HAL Id: hal-01738328 \\ https://hal-audencia.archives-ouvertes.fr/hal-01738328}

Submitted on 23 Mar 2018

HAL is a multi-disciplinary open access archive for the deposit and dissemination of scientific research documents, whether they are published or not. The documents may come from teaching and research institutions in France or abroad, or from public or private research centers.
L'archive ouverte pluridisciplinaire HAL, est destinée au dépôt et à la diffusion de documents scientifiques de niveau recherche, publiés ou non, émanant des établissements d'enseignement et de recherche français ou étrangers, des laboratoires publics ou privés. 


\title{
A FRAMEWORK TO STUDY STRATEGIZING ACTIVITIES AT THE FIELD LEVEL: THE EXAMPLE OF CSR RATING AGENCIES
}

\author{
Tamim Elbasha \& Emma Avetisyan \\ Audencia Business School
}

\begin{abstract}
This paper responds to recent calls to bridge strategy and organization research by combining Strategy-as-Practice and Neo-Institutional Theory through re-theorizing the notion of strategic actor. We problematize the notion of strategic actor at the field level, and rely on insights from management and organization studies and sociology to advance a theoretical framework that conceptualizes organizations as social actors at the field level. We demonstrate our theoretical framework by drawing on corporate social responsibility rating agencies. We see corporate social responsibility rating agencies as supra-individual, social actors that are predisposed to assume an active role in defining and revisiting structural parameters within the society through their purposeful, meaningful actions and interactions. Our main contribution is to the development of the Strategy-as-Practice literature, achieved by re-theorizing the notion of strategic actor at the field level. This contribution responds to the micro-isolationism critique, and proposes a new focus for Strategy-as Practice research.
\end{abstract}

Keywords: strategy-as-practice, neo-institutional theory, CSR rating agencies 


\section{INTRODUCTION}

In the past decade, Strategy-as-Practice research (SaP) had moved away from a view of strategy dominated by micro-economics, and conducted research into individuals' roles in strategizing (Jarzabkowski \& Whittington, 2008). Strategy, according to this strand of research, is the doing of social actors (Balogun, Jarzabkowski \& Seidl, 2007; Johnson, Melin \& Whittington, 2003). SaP research has therefore been preoccupied with strategizing praxis at the individual level (Carter, Clegg \& Kornberger, 2008) leading to research papers criticized for their microisolationism (Seidl \& Whittington, 2014), i.e. a self-imposed limitation to the individual, micro level.

In their recent call, Suddaby and colleagues invited researchers to adopt complementarities from Neo-Institutional Theory (NIT) to balance the SaP research agenda towards macro-level issues (Suddaby, Seidl \& Lê, 2013). In this paper we take up this invitation and ask: how could we combine NIT and SaP to address the longstanding micro-isolationism critique of SaP? Our response involves seeking complementarities from NIT to challenge one of the taken-for-granted assumptions within $\mathrm{SaP}$ that strategizing activities are carried out by individuals. The present paper re-theorizes strategic actors as a way to combine the two perspectives (Suddaby et al., 2013), thus responding to the micro-isolationism critique of SaP (Carter et al., 2008; Seidl \& Whittington 2014).

Our re-theorization relies on recent developments in management and organization studies (King, Felin, Whetten, 2010) and on sociological perspectives (Bhaskar, 1979; Cohen, 1989; Geser, 1992, 2002; Giddens, 1984; Stones, 2005) to argue that many organizations act as social actors, separate from the individual social actors who constitute them. We support the SaP thesis in believing that strategy is not a static property possessed by organizations, but is continuously created in strategy work (Jarzabkowski, Spee \& Smets, 2013) and embedded in 
the actions and interactions of social actors (Jarzabkowski, 2004). However, we propose that strategy could be seen as something that organizations, not solely the individuals belonging to them, do (King et al., 2010). In order to understand strategizing activities of organizations, we mobilize the work on supra-individual actors (Geser, 1992, 2002) and the notion of positionpractices (Bhaskar, 1979; Cohen, 1989; Stones, 2005) at the 'field' level (DiMaggio \& Powell, 1983; Powell \& DiMaggio, 1991). By doing so, we unravel the characteristics of organizations as social actors (King et al., 2010) as opposed to economic actors who seek profit maximization above all (Chandler, 1962; Porter, 1980). To explicate our conceptual framework, we use the example of Corporate Social Responsibility (CSR) rating agencies revealing how these agencies can be seen to engage in strategizing behaviors with other social actors within the society. This application is not meant to be an empirical investigation, but rather as a way to exemplify our conceptual framework.

Recently, a handful of papers have combined the two perspectives (SaP and NIT) by simultaneously borrowing concepts from both sides to study a phenomenon of interest (Jarzabkowski et al. 2013; Smets \& Jarzabkowski 2013; Smets, Morris \& Greenwood, 2012; Smets, Jarzabkowski, Burke \& Spee, 2015). This paper, by contrast, combines the two approaches to take a critical stance on a taken-for-granted assumption in SaP. Our main contributions to the SaP literature are: 1) re-theorizing the notion of strategic actor at the field level, proposing a new focus of research; 2) offering a response to the long-standing criticism of SaP of being absorbed by the individual level; and 3) elaborating a much-needed theoretical framework to combine SaP and NIT in a way that goes beyond simply borrowing concepts from both sides. NIT scholars may see our conceptual development as one way to explain how some organizations escape isomorphism. We also believe that the exemplification of our theoretical development opens interesting perspectives for studying CSR rating agencies, as social actors, from different aspects. This new proposition stands in contrast to the current focus 
in the literature on CSR rating agencies' data to operationalize the Corporate Social Performance (CSP) construct.

This paper proceeds in four main sections. First, we briefly revisit SaP and NIT to iterate their primary focus on the individual and institutional levels respectively; this revisit doesn't therefore aim to provide a comprehensive review of these two literature streams. The discussion then shifts to current studies that combine the two perspectives. Second, we discuss the core theoretical concepts underpinning our conceptual framework (Figure 1). We turn to the work of King et al. (2010) to establish the ontological foundations of theorizing organizations as social actors. We then elaborate these ontological foundations by turning to social theory, particularly the notions of supra-individual actors (Geser, 1992, 2002) and position-practices (Bhaskar, 1979; Cohen, 1989; Stones, 2005). The third section exemplifies our framework by drawing on the actions and interactions of CSR rating agencies. The last section offers a discussion of our theoretical development and a conclusion.

\section{ON COMBINING STRATEGY-AS-PRACTICE AND NEO-INSTITUTIONAL THEORY}

\subsection{Strategy-as-Practice}

Recently, strategy research has paid more attention to the 'doing' of strategy (Balogun \& Johnson, 2005; Jarzabkowski \& Seidl, 2008; Jarzabkowski et al., 2013; Mantere, 2005; Vaara \& Whittington, 2012; Whittington, 2003;). Thus, the SaP perspective uses the term 'strategizing' to refer to the actions and interactions related to strategy work (Jarzabkowski, Balogun \& Seidl, 2007), seeing strategy as a "situated, socially accomplished activity" and a "goal-oriented activity within an organization" (Jarzabkowski, 2005: 7-8). Strategizing comprises the continuous, purposeful movement towards and along organizational strategies and goals that involves meaningful actions carried out by social actors (Whittington \& Melin 
2003: 35). Strategizing, then, can be viewed as a "culturally shaped accomplishment attained through historically and culturally transmitted social practices and involving dispositions, propensities and tendencies" (Chia \& MacKay 2007: 23).

SaP has been considered as a welcomed move from an economics-based to a socialbased view of strategy (Vaara \& Whittington, 2012). When SaP scholars investigate strategizing within organizations, they draw extensively on social practice theories such as structuration theory (Giddens, 1984), Foucault's (1982) work, and the works of Bourdieu (Bourdieu, 1990; Bourdieu \& Nice, 1977). Through its focus on social actors and their roles in the strategizing process, $\mathrm{SaP}$ has been naturally preoccupied with the practices and praxes of individuals, or aggregates of individuals, at different organizational levels (Jarzabkowski \& Spee, 2009).

First, SaP empirical research has been looking at traditional strategy actors, such as top managers and consultants. We are now more informed about the roles and interactions of senior management teams to formulate strategy (e.g. Angwin Sotirios \& Mitson, 2009; Jarzabkowski, 2008), how managers develop and deploy issue-selling techniques during strategy formulation (Howard-Grenville, 2007), the engagement of top managers and external consultants during business dinners (Sturdy, Schwartz \& Spicer, 2006), the discursive movements of consultants to influence strategy (Lain \& Varra, 2007), and how managers' use of presentation slides influences the outcomes of strategy meetings (Kaplan, 2011). SaP scholars equally paid a special attention to the roles, actions and interactions of these important strategic actors during strategy formulating episodes, such as meetings and strategy away days (e.g. Bourque \& Johnson, 2008; Hendry \& Seidl, 2003; Jarzabkowski \& Seidl, 2008).

Second, SaP shed an important light on the strategic practices and praxes of previouslyneglected social actors. An impressive body of work has been produced on the roles and activities of middle managers in strategy formulation and implementation, as champions of 
strategy (Mantere, 2005), skillful sellers of strategic change (Rouleau, 2005) and skilled interpreters of strategy (Suominen \& Mantere, 2010). Researchers in this stream have unearthed some conditions under which middle managers become more active participants in strategy (Hoon, 2007; Mantere, 2008). Furthermore, strategic actors at the peripheries are attracting more attention from $\mathrm{SaP}$ scholars. A recent study discussed how the day-to-day practices of museum guides play a role in delivering the strategy of their organizations (Balogun, Best \& Le, 2015), and another illustrated how insurance brokers drew on institutional logics in their day-to-day practices (Smets et al., 2015).

SaP studies overall share a fascination with the detailed, nitty-gritty work of managers as they go about their daily routines. Even when studying an aggregate of individual actors, $\mathrm{SaP}$ researchers tend to stay within organizational boundaries. For example, Balogun \& Johnson's (2005) study looks at sensemaking among a group of middle managers within the company, describing how existing organizational schemata are altered, reinforced and merged as middle managers enact their agency, and Herepath's study (2014) examines the influence of political landscape on the strategizing practices of a group of top managers within the National Health Service. As a result, $\mathrm{SaP}$ has been accused of overwhelmingly focusing on the individual, and the micro level of analysis. Positioned too close to the managers and their conduct, $\mathrm{SaP}$ research risks losing connections with the wider societal context; and the ability to reflect on the overall value and consequences of the organization strategy (Carter, 2013). This fascination with the micro level could perhaps be seen originating from an early turn in SaP, when Johnson et al. (2003: 14) declared in a seminal work "it's time to shift the strategy research agenda towards the micro", thus inviting studies that examine micro-activities that have strategic outcomes. More recently, this tendency has been described as 'micro-myopia' (Vaara \& Whittington, 2012: 28) or 'micro-isolationism' (Seidl \& Whittington, 2014). These 
terms capture how SaP researchers zoom in on the micro level without sufficient consideration for macro level impact and effects.

\subsection{Neo-Institutional Theory}

NIT originated around forty years ago in response to functional explanations of organizational practice (Meyer \& Rowan, 1977; Scott \& Meyer, 1983). It emphasizes the relationship between organizations and their environment, and is sceptical towards rational-actor models of organization (Powell \& DiMaggio, 1991). NIT scholars focus on non-local environments roughly conterminous with the boundaries of industries, professions, fields or national societies, therefore replacing the invisible hand of the market with macro-culture and macrodiffusion patterns (Scott \& Meyer, 1983). This stands in contrast to the old institutional theory, which described organizations and actions embedded in face-to-face local communities (Selznick, 1949; Gouldner, 1954; Dalton, 1959; Clark, 1980). Also, if the older institutionalists had regarded organizations as both the units that were institutionalized and the key loci of the process, NIT viewed institutionalization as occurring at the society and field levels consequently its locus was interorganizational (Powell \& Dimaggio, 1991).

Hence, several institutionalists have designated the concept of the 'field' as being central to NIT analysis (DiMaggio \& Powell, 1983; Powell \& DiMaggio, 1991; Scott, 2008; Scott \& Meyer, 1983). Consequently, organizational field became an intermediate unit between, at microlevels, individual actors and organizations and, at macrolevels, systems of societal and trans-societal actors (Scott, 2008). Moreover, the concept of the field, identified as a system of actors, actions, and relations whose participants take one another into account as they carry out interrelated activities, allows us to view these actors in context, rather than focusing on a single organization or movement, or even a single type of organization or population (McAdam \& Scott 2005: 10). 
NIT turned to cognitive and cultural explanations (DiMaggio \& Powell, 1991) and tended to talk about how homogeneous organizations become in their observable features in response to macro-institutional structures (DiMaggio \& Powell, 1983). DiMaggio \& Powell's (1983) founding publication in new-institutional theory extended the prior ideational elements of neo-institutionalism by suggesting that organizations adopting a similar structural position in an organizational field will become isomorphic with their common institutional environment. In his seminal article Suddaby (2010) asserts that until recently the subsequent studies in new institutional theory unfortunately ignored the ideational elements (rationalized myths, legitimacy and taken-for-grantedness) of DiMaggio and Powell's (1983) argument and, somewhat blindly, pursued the structural implications of isomorphism (Mizruchi \& Fein, 1999). He sees a danger that the theory has been stretched far beyond its core purpose- to understand how organizational structures and processes acquire meaning and continuity beyond their technical goals (Suddaby, 2010: 14). Indeed, the volume of studies conducted on the influence of organizational field-level factors within-field isomorphic processes has been overwhelming (Boxenbaum \& Jonsson, 2008) in comparison to between-field studies, leading to calls to examine between-field variability in isomorphic processes. (Heugens \& Lander, 2009).

\subsection{Finding common grounds between SaP and NIT}

In recent years, the academic literature evidenced a new strand of research that drew on both SaP and NIT (Jarzabkowski et al., 2013; Smets \& Jarzabkowski 2013; Smets et al., 2012; Suddaby et al., 2013; Smets et al., 2015). This emerging stream of research drew on a collective pool of concepts from both perspectives to offer new explications of several ill-understood phenomena. For instance, Smets et al. (2012) combined practice and NIT approaches to unpack the way actions at the individual level can produce effects at the institutional level. Similarly, 
Jarzabkowski et al. (2013) invited researchers to study individuals' practical understanding as a way of explaining institutional ambidexterity; while Smets and Jarzabkowski (2013) offered a model to explain the role of actors' agency in institutional work. Most recently, Smets et al. (2015) studied institutional complexity and incompatible logics within the day-to-day work of reinsurance traders. Combining theoretical lenses with different underlying assumptions has been encouraged as a method to study imprecise phenomena (Okhuysen \& Bonardi, 2011), and seizing and conjoining concepts from both NIT and SaP has added novel insights to our current understanding. However, we argue that combining $\mathrm{SaP}$ and NIT can yield even more stimulating outcomes by challenging some of the taken-for-granted assumptions on either side.

How could we, then, combine the SaP and NIT perspectives beyond the shy conjoining of the concepts they offer? Suddaby et al. (2013) examined the different assumptions underpinning the two research areas, suggesting two interrelated future research directions that would combine SaP and NIT. They invited scholars to 1) re-theorize our understanding of strategic actors and their agency whilst 2) considering them within their immediate context, that is to say their actions and interactions with other social actors in the society (Suddaby et al., 2013). The present paper takes up this challenge, and elaborates a conceptual framework to advance our understanding of organizations as strategic and social actors within their context at the field level. We maintain that one promising approach to combine $\mathrm{SaP}$ and NIT is through studying the strategizing actions and interactions of organizations at the field level.

\section{CENTRAL THEORETICAL CONSTRUCTS}

\subsection{Organizations as social actors}

Conceiving organizations as supra-individual social actors (Geser, 1992, 2002; King et al., 2010) is a significant development in bridging SaP and NIT. From the NIT point of view, this 
provides the theoretical base to understand the ability of some organizations to escape isomorphism (Alvarez, Mazza, Pederson \& Svejenova, 2005) whilst retaining the premise that organizational actions are influenced by structural pressure (Powell \& DiMaggio, 1991). From a SaP point of view, theorizing organizations as social actors retains the core belief that social actors are 'creative' (Emirbayer \& Mische, 1998; Stones, 2005) in the sense that organizations are able to envisage various future alternatives. Treating organizations as social actors allows $\mathrm{SaP}$ to shift the focus from individuals and their micro strategizing practices to organizations and their strategic actions (King et al., 2010).

King et al. (2010) argued that the vast majority of management and organization studies treated organizations as the aggregation of their individual actors, therefore diluting the possibility to study organizations as the unit of analysis. Some exceptions do exist, such as Hannan and Freeman's work on population ecology (Hannan \& Freeman, 1984), which likened organizations to living beings, and Coleman's discussion of constructed organizations (Coleman, 1991) and output-driven organizations (Coleman, 1993). Nevertheless, King et al. (2010) claimed, such exceptional work fell short of developing a solid ontological foundation to conceptualizing organizations as social actors. They (King et al., 2010) therefore advanced two underlying ontological assumptions.

First, organizations have intentions that guide their decisions and behavior, or what the authors (King et al., 2010) labeled 'the intentionality assumption'. Second, organizations are considered as social actors insofar as they are perceived as such by other social actors; this is what King and his colleagues called 'the external attribution assumption'. Without undermining the importance of King et al.'s (2010) seminal work in providing ontological foundations to place the organization at the center of management and organization research, 
two main shortcomings manifest. First, in their intentionality assumption, King et al. (2010) fell short of explaining whether all organizations, or only some, have intentions to drive their actions, and how distinct these intentions are from the intentions and actions of the actors who constitute the organization. Second, the external attribution assumption does not clarify the source of that attribution.

Addressing these two shortcomings is important to advance our understanding of the unique qualities of organizations as social and strategic actors, and how their actions and interactions, as the outcomes of organizational processes, are shaped by and affect their context. Inspired by SaP, we address the above two shortcomings by turning to social theory. First, we rely on the works of Geser $(1992 ; 2002)$ on supra-individual actors to elaborate the intentionality assumption; hence understanding when and why organizations can act in a way that is distinctive from the actions of their member. Second, we use the notion of positionpractices (Bhaskar, 1979; Cohen, 1989; Giddens, 1984; Stones, 2005) to unearth the source of external attribution assumption. Our developments are summarized in Figure 1, and presented in the next two sections.

\section{INSERT FIGURE 1 ABOUT HERE}

\subsection{Supra-individual actors}

According to Geser (1992, 2002), some organized collectivities escape from an exclusive commitment to their members. These organizations form a supra-individual social actor through creating their own value systems, norms and strategies distinctively from their members'. 
Referring to an organization as a supra-individual actor is dependent on meeting two necessary conditions (Geser, 2002). First, organizations must have processes of their own that serve as a decision-making mechanism beyond that of their individual members. Modern organizations fulfill this criterion through structures, policies and procedures. Such processes are independent of individual members in the organization (Levitt \& March, 1988) and have clear effects or outcomes such as assigning power, regulating legitimacy, establishing norms and so forth. The second condition is the ability to describe some of these effects or outcomes as meaningful actions (Geser, 2002). When compared with individuals, organizations are more inclined to act in a goal-oriented way by setting aims and engineering their processes and resources in order to achieve these aims (Coleman, 1993). Entering markets, merging and applying for patents are all examples of meaningful, purposeful intentions and actions that emerge partially or totally as a result of organizational processes, and which are attributed to the organization and not to employees (e.g. Chattopadhyay, Glick \& Huber, 2001; Zavyalova, Pfarrer, Reger \& Shapiro, 2012). Geser's $(1992,2002)$ two conditions spell out when it is possible to distinguish the intentions of an organization from those of the actors that constitute it, hence donating a nuanced assessment of the intentionality assumption in King et al.'s (2010) work.

Geser $(1992,2002)$ came to the conclusion that supra-individual actors were constituted and identified by their actions, predisposing them to have an active role in the restructuring of their social and societal environment. Actions taken by supra-individual actors draw upon internal, such as decision-making or resource-allocation processes, and external, such as goalseeking and societal obligations, structural properties (Giddens, 1984; Stones, 2005). This drawing upon provides organizations with the possibility to maintain or elaborate these pre- 
existing structures (Barley \& Tolbert, 1997; Stones, 2005). Moreover, actions taken by supraindividual actors should also be seen within a temporal dimension, hence influenced by patterns from the past, pressing emerging conditions from the present and an orientation towards the future (Emirbayer \& Mische, 1998). Indeed, strategic management literature discusses path dependency (e.g. Vergne \& Durand, 2010), whereby organizations' previous experiences create a pattern that strongly influences their new strategic decision-making when they plan for their future.

\subsection{Supra-individual actors within their context}

The second ontological assumption made by King et al. (2010), the external attribution assumption, exposes how social actors in a given context recognize organizations as social actors on their own. This paper argues that organizations are qualified as supra-individual social actors by other actors because of the obligations, expectations, prerogatives and propensities offered, and imposed upon, by their structural terrain and other supra-individual actors within that terrain. Supra-individual actors take a 'position'; i.e. they do not simply fill a role in social space (Bhaskar, 1979; Coad \& Glyptis, 2014; Cohen, 1989; Giddens, 1984; King et al., 2010; Stones \& Tangsupvattana, 2012;).

Concepts related to social positions were developed through the works of Giddens (1979, 1984), Bhaskar (1979), Cohen (1989) and Stones (2005). Giddens problematized the notion of social roles, arguing that such a concept limits the performativity of social practice since it assumes a described set of structural restraints (Giddens, 1984). Giddens went as far as defining a social position as social identity, which serves as a social category associating distinct social criteria such as age and occupation (Giddens, 1984). Usually social actors have multiple social identities simultaneously, for instance a specialist; a leader and a nationalist, in 
the sense that having these social identities is associated with some social obligations and prerogatives (Giddens, 1979; Whittington, 1992).

Bhaskar had a more developed version of this notion taking into account the practices associated with social positions. For Bhaskar, these position-practices acted like slots in which social actors would slip in as they drew upon and reproduced social structures (Bhaskar, 1979). Later, Cohen argued that both Giddens' and Bhaskar's notions were in need of refinement and development. It was better, Cohen argued, to define position-practices in a way that would declare them as basic units of institutionalized systems (Cohen, 1989). Furthermore, Cohen explained that scholars needed to pay due attention to the interrelations between different positions-practices, or what he called position-practice relations (Cohen, 1989).

The current discussion of position-practices in sociology concerns individual social actors. However, it can be reasonably applied to the supra-individual genre of social actors. For instance, describing an organization as a 'university', a collectivity that qualifies as a supraindividual actor, entails certain obligations, expectations, prerogatives and propensities, which are set and offered by the structural context, and other actors, to this particular positionpractice. Universities are expected to provide education, to advance scientific research, to be a good citizen and so on. Further, universities have the power to certify knowledge, and are inclined to help students in gaining such knowledge. These affordances and expectations are set by the education sector, by other supra-individual actors such as other universities, research centers and companies; and by other types of social actors that do not qualify as supraindividual actors such as unions of employees, students and top management teams. 
To sum up our discussion so far, this paper advances the study of strategizing by organizations at the field level as a research area suitable for combining both the SaP and NIT perspectives. King et al.'s (2010) notable work unearthed two ontological assumptions - the intentionality assumption and the external attribution assumption - that underlined the conception of organizations as social actors beyond the simple representation, or the sum, of the social actors that constitute them. Elaborating these assumptions is vital to appreciate the unique qualities of organizations as strategic actors, and how their strategizing actions and interactions are shaped by and influence the society. Geser's work $(1992,2002)$ detailed the nature of supraindividual actors, setting conditions under which organizational intentions are distinctive from the intentions of aggregate actors. Supra-individual actors are constituted by their meaningful and purposeful actions, a feature that sets them apart from individual actors. These actions play an active role in restructuring the social context. Geser's rich view on supra-individual actors allows us to nurture the intentionality assumption. Mobilizing the notion of position-practices (Bhaskar, 1979; Cohen, 1989; Giddens, 1984; Stones, 2005) offers us the opportunity to account for the external attribution assumption through examining the obligations, expectations, prerogatives and propensities both offered and imposed by the structural terrain.

\section{EXEMPLIFICATION OF THE THEORETICAL FRAMEWORK}

This section starts by presenting the mounting interest of SaP and NIT scholars in CSRrelated phenomena. The concept of the organizational field, taken from NIT, helps us set a boundary, the structural context within which we demonstrate the supra-individuals' strategizing phenomenon. This is followed by presenting the context of CSR rating agencies and their suitability as exemplification of our conceptual framework. We then turn to our conceptual framework, returning to Geser's two conditions and how CSR rating agencies meet these conditions, and therefore can be considered supra-individual actors constituted by their 
actions. Lastly, we discuss the purposeful actions and interactions between CSR rating agencies and other actors in the field as the strategizing work of these supra-individual actors.

\subsection{SaP and NIT in CSR studies}

In the past two decades, both NIT and SaP literatures have been showing a growing interest to study CSR-related issues.

From a SaP perspective, studies examined topics such as the convergence between CSR and strategic management discourse (Brooks, 2005), business ethics as practice (Clegg, Kornberger \& Rhodes, 2006), corporate governance (Palmer \& O'Kane, 2007), the introduction of CSR policies within organizations (Sharp \& Zaidman, 2010) and the interplay between economic and non-economic motivations underlying CSR policies (van Aaken, Splitter \& Seidl, 2013). Indeed, SaP has been identified as a promising area for a more context-responsive CSR research (Anthanasapoulou \& Selsky, 2012), which is capable of handling CSR as a cross-level phenomenon with multiple levels and perspectives.

CSR scholars have also been showing mounting interest in institutional theory and its application to understand CSR-related phenomena. Leading scholars (e.g. Brammer, Jackson \& Matten, 2012) recently argued that applying the lens of institutional theory to the study of CSR allows for a better understanding of business responsibilities in two chief aspects: diversity and cross-national variations of CSR practices (Doh \& Guay, 2006; Gjolberg, 2009, 2010; Jackson \& Apostolakou, 2010; Marquis, Glynn \& Davis, 2007; Matten \& Moon, 2008) and the dynamics of CSR, which corresponds largely with the two dominant schools of thought in institutional theory that emphasize the global diffusion of practices and the adoption of these by organizations respectively (Tempel \& Walgenbach, 2007).Recently, CSR researchers referred to the concept of CSR as an organizational field that aims to regulate corporate behavior across a variety of institutional arenas (Campbell, 2007; Gond, Kang \& Moon, 2011; 
Matten \& Moon 2008; Scherer \& Palazzo, 2011; Windsor 2006). Campbell (2007), for instance, focused on the institutional determinants of CSR, and how organizations would maneuver within the forces at the interorganizational field level. Matten and Moon (2008) also referred to the term 'organizational field of CSR', explaining that governments were not considered as key actors in the CSR organizational field, but rather as arenas where different interests were played out. More recently, Scherer and Palazzo (2011) presented the emerging debate on political CSR within the CSR field itself, and other debates in the wider context, mainly in legal studies; international relations and political philosophy, that have contributed new insights and alternative views. In that study, the term 'CSR field' encapsulates various notions such as business ethics, business and society, corporate accountability, corporate citizenship, corporate sustainability, critical management studies and stakeholder theory. Lastly, Avetisyan and Ferrary (2013) conceptualized CSR as an emerging field that comprised various interested 'permanent' and 'temporary' (Boutinot \& Mangematin, 2013) actors (institutional investors, governments, NGOs, companies, CSR rating agencies, academia, policy-makers and so forth) who entered the field at different periods of time and contributed to its institutionalization.

\subsection{CSR Rating Agencies}

We now exemplify our conceptual framework (Figure 1) by drawing on CSR rating agencies. These agencies provide investor-solicited and company-solicited rating services; corporate research; and compliance and consulting services for a broad array of stakeholders (Avetisyan and Hockerts, 2016). To conduct their analysis, CSR rating agencies use public documents such as governmental databases and press releases; companies' financial, environmental, social and sustainability reports; specific questionnaires and meetings with the heads of companies. CSR rating agencies are central actors and institutional entrepreneurs within the CSR field, 
actively contributing to its institutionalization (Avetisyan \& Ferrary, 2013). They are placed at the interface with other CSR field actors, such as companies; investors; field experts; academia; governments and civil actors. As such, they are particularly relevant to exemplify our conceptual framework offering a window to illustrate their strategizing actions with the society.

\subsection{CSR rating agencies as supra-individual actors}

How do CSR rating agencies fulfill Geser's two conditions? Firstly, CSR rating agencies have created their own processes, which are independent of the individual members of these organizations. These processes include the agencies' methodologies, screening type (positive or negative), service type (investor-solicited or company-solicited), CSR metrics and appropriate weights (Scalet \& Kelly, 2010). For example, Eiris - the first UK based CSR rating agency has kept over the past thirty years its not-for-profit organizational status. Eiris does not accept fees from companies that it rates and considers it as a conflict of interest. Eiris' processes reflect the organization intention to provide independent research and be removed from the shareholder-value-maximization goal of most investors (Avetisyan \& Hockerts, 2016). This has been a constant intention for the organization, independent of the intentions of the various employees who worked there in the past three decades.

Secondly, the activities of CSR rating agencies are meaningful as they have an impact on the actions of other actors in the field - particularly for companies and investors. Over time, addressing CSR issues has become an emerging part of the competitive strategy of companies (Galbreath, 2013) as they value their ratings and communicate about the subject, both internally and externally (Slager, Gond \& Moon, 2012). On the investor side, ratings produced by CSR rating agencies are found useful to make relevant investment decisions because CSR issues are increasingly viewed as being financially 'material' to an investment portfolio (Richardson, 
2009). Several responsible indexes developed by CSR rating agencies, for instance ASPI (developed by Vigeo) and FTSE4Good Index series (built up using Eiris data), have become reference points and a de facto standard within the responsible investment field; they have achieved visibility both in the mass media and in the financial marketplace (Déjean 2005; Slager et al., 2012).

Furthermore, the activities of CSR rating agencies are purposeful, as these activities have been engineered to establish the legitimacy of these agencies within the CSR field. Hence, these activities are strategizing activities (King \& Walker, 2014). Over the past three decades, CSR rating agencies have been proactive participants in the various discussions and consultations that have led to international standards and guidelines such as ISO 26000, Global Reporting Initiative (GRI), United Nations Principles of Responsible Investment (UNPRI) and other initiatives CSR rating agencies were invited to these interactions as experts in the field, hence their methodologies and evaluation criteria were viewed as trustworthy and reliable. This proactive participation was carried out in tandem with other purposeful interactions with powerful actors such as academia. For instance, KLD was the first rating agency to give its data to Professor Sarah Waddock and statistician Samuel Graves (Gond \& Avetisyan, 2016). The paper by Graves and Waddock (1994) was the first paper using the KLD dataset that was published in the Academy of Management Journal. Since then, the KLD dataset has been cited as the 'de facto 'research standard' for CSR measurement in academia (Waddock 2003: 369), and as a proxy for CSP (Sharfman, 1996; Waddock \& Graves, 1997).

These purposeful, meaningful actions and interactions aimed to, and succeeded in establishing the agencies' legitimacy vis-à-vis other actors of the CSR field. They were carried out through a continuous process, involving an ongoing interaction between CSR rating agencies and other actors in the field such as investors, companies and governments. 


\subsection{Situating CSR rating agencies as supra-individual actors within the society}

The structural position of CSR rating agencies at the interface of other actors in the CSR field both offer and impose certain obligations, expectations, prerogatives and propensities. In fact, different historical contexts and national business systems have exerted different types of global institutional and socio-political pressures on CSR rating agencies and their actions. In the United States, CSR rating agencies favor the exclusionary, or negative, screening approach. For instance, these agencies exclude companies with substantial investments in controversial sectors such as tobacco and alcohol, or those who are involved in practices considered immoral or non-responsible (Chatterji, Durand, Levine \& Touboul, 2016). By contrast, French CSR rating agencies introduced a clear break by applying the positive or best in class approach. Differences equally transpose to the finer, rating criteria level. For example, KLD, a U.S.-based CSR rating agency assigned $71 \%$ of its sub-categories to social issues, whereas Asset4, a European rater, related only $47 \%$ of its sub-categories to social issues (Chatterji et al., 2016).

As a result of interactions with, and expectations from investors; companies; field experts; government; academia and other powerful or legitimate actors of the CSR field, rating agencies have materialized, integrated and reshaped several social and environmental issues in their CSR assessment criteria. CSR rating agencies constantly add/modify certain evaluation criteria, following the appearance of new emerging issues and standards, or remove issues that are no longer relevant or cannot be quantified because of data scarcity. For example, in the early 2000s, when the relationship between KLD's activity and the stakeholder model of the corporation became clearer, KLD reorganized its assessment criteria (Gond \& Avetisyan, 2016); it renamed some general categories to give them a stakeholder-model flavor in order to communicate its intentions in a better way, such as renaming 'Non-US Operations' to 'Human 
Rights' and 'Other' to 'Corporate Governance'. During the same period, Vigeo - a CSR rating agency based in France - renamed its 'Shareholders' domain to 'Corporate Governance' and 'Civil Society' to 'Community Involvement'. Finally, both the FTSE4Good Index series (by Eiris) and the DJSI (by SAM Group) have added assessment criteria for issues such as climate change and supply chain standards in the last decade (Slager \& Chapple, 2015).

Summing up the exemplification of our conceptual framework, CSR rating agencies are predisposed to actively engage in defining and revisiting the structural parameters of their societal context. This involves purposefully taking action and taking part in continuous interaction with other social actors in the field. These actions and interactions are attributed to the CSR rating agencies, not to the individuals or the employees that constitute them. As supraindividual actors, CSR rating agencies have been strategizing to establish their legitimacy, increase their influence and ensure their survival within the society. This strategizing is evident through their meaningful, purposeful actions and interactions in the CSR field.

\section{DISCUSSION AND A CONCLUSION}

The theoretical developments offered in this paper advance the SaP research agenda at least in three ways. Firstly, the current $\mathrm{SaP}$ research agenda assumes that individual actors, or aggregations of actors, carry out strategizing work. The present paper offers a critical view on this taken-for-granted assumption by advancing that organizations, under certain conditions, can be seen as strategic and social actors who carry out strategizing activities through their actions and interactions with other actors in the field. This social view on organizations is distinctive from the traditional work within the strategic management literature, which considered organizations as economic actors pursuing profit maximization (e.g. Chandler, 1962; Grant, 1991; Porter, 1980;). Studying the strategizing work accomplished by 
organizations, as social actors, with the society opens up a new research avenue for the thriving SaP research community.

Secondly, SaP research has been frequently criticized for being overly concerned with the micro and individual levels of analysis (Carter et al., 2008; Seidl \& Whittington, 2014). Our paper offers a response to this critique by elaborating a theoretical framework to retheorize our understanding of strategic actors in the field, hence at a more macro level. Our framework offers SaP research a way to shift the level of analysis from the individual to the interorganizational and field levels.

Thirdly, the present research responds to a recent call to bridge strategy and organization research by combining the SaP and NIT perspectives (Suddaby et al., 2013). In particular, we argue that one fruitful way to combine the two theories is to challenge a takenfor-granted assumption in SaP, surpassing the currently dominant approach of borrowing and conjoining concepts from both streams.

The present paper also contributes to the thin literature that invites researchers to conceptualize organizations beyond the aggregation of their employees. Currently, this literature seemingly aims to develop the ontological level (Geser, 1992, 2002; King et al., 2010). Building on these ontological concepts, our theoretical framework elaborates muchneeded details on the characteristics of organizations as social actors, thus moving the discussion towards more empirical grounds.

Since our feet are strongly trenched in the SaP perspective, our work offers a more modest contribution to the NIT literature by responding to recent calls to cross-fertilize 
institutional and strategic management (Durand, 2012). The theoretical advances made in this paper could provide a foundation to explain the ability of some organizations to escape isomorphism (Alvarez et al., 2005). We suggest that our understanding of this phenomenon could be improved through studying both the restraining and enabling conditions in the immediate context of organizations at the field level, especially obligations, expectations, prerogatives and propensities. To give an example drawn from our case, CSR rating agencies in the USA and France developed different screening approaches and CSP evaluation criteria. This is coupled with the assumption that organizations, as supra-individual actors, are able to envisage different future alternatives and therefore take purposeful actions to realize these alternatives.

The bulk of empirical research has investigated the CSP-Corporate Financial Performance (CFP) link using datasets of CSR rating agencies. Although this upsurge in the number of academic publications in top academic journals and more specialized outlets has resulted in improving our understanding of the topic, we believe that CSR rating agencies merit attention that goes beyond understanding the relationship between CSR and its impact on CFP. Given the role of CSR rating agencies in the construction of calculative standards designed to institutionalize the CSR field, we see interest in studies that will examine these agencies on their own: unveiling the processes of methodology creation and index production enabled and constrained by the social position of CSR rating agencies within the society. Systematic empirical investigation of the strategies of CSR rating agencies within the CSR field might be particularly interesting. Building on Battilana, Leca and Boxenbaum's (2009) study, we also suggest exploring the interaction effects between two categories of enabling conditions for CSR rating agencies: field characteristics and the actors' social positions, which may play an important role in enabling institutional entrepreneurship in this field. Lastly, as an extension of 
Stål, Bonnedahl and Eriksson's (2014) study we invite other researchers to study how extrafield influences affect Institutional Entrepreneur's (CSR rating agencies) propensity to suggest and promote change in CSP evaluation. Finally, we as with any conceptual paper, our theoretical framework can benefit greatly from empirical testing. 


\section{Figure 1 - A Theoretical Framework to Study Strategizing at the Field Level}

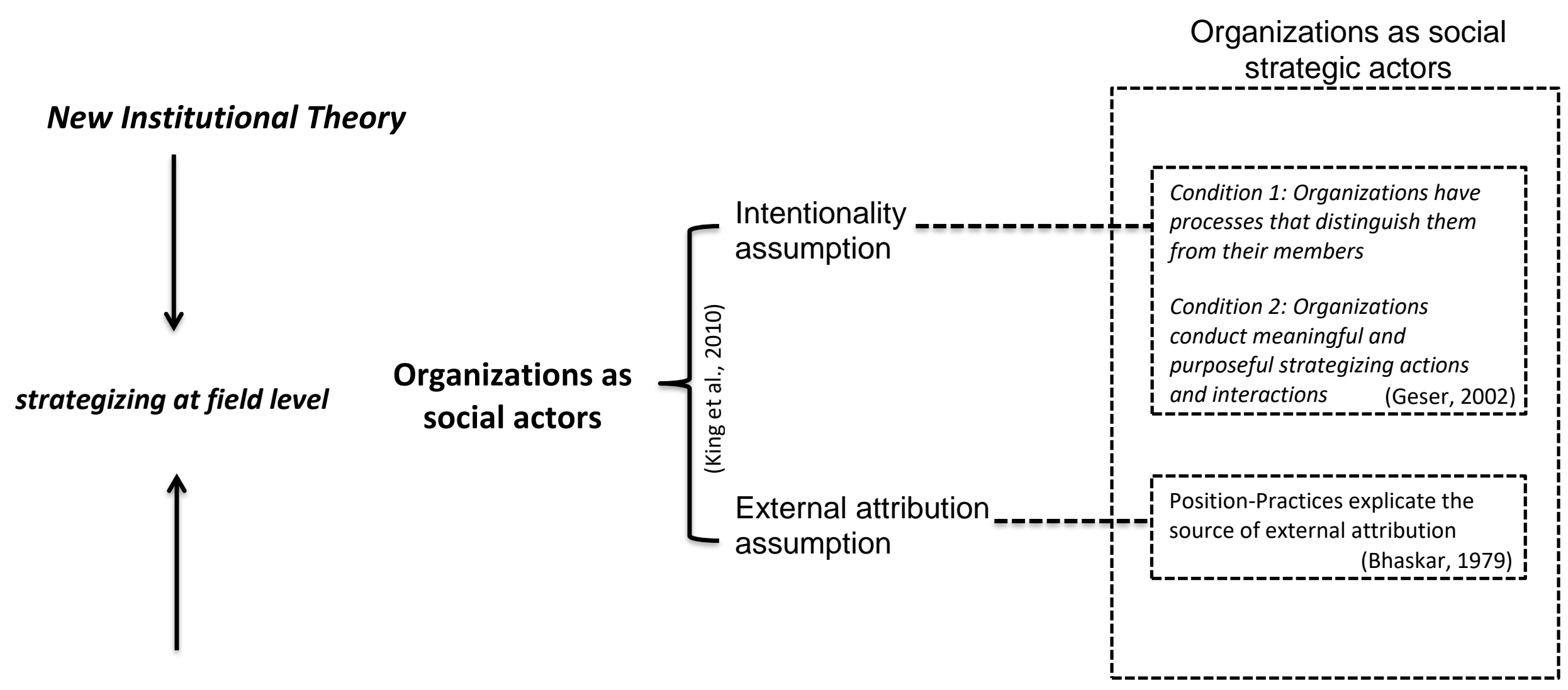

Strategy-as-Practice 


\section{REFERENCES}

van Aaken, D., Splitter, V., \& Seidl, D. (2013). Why do corporate actors engage in pro-social behaviour? A Bourdieusian perspective on corporate social responsibility. Organization, 20(3), 349-371.

Alvarez, J.L., Mazza, C., Pederson, J. S., \& Svejenova, S. (2005). Shielding idiosyncrasy from isomorphic pressures: Towards optimal distinctiveness in European filmmaking. Organization, 12(6), 863-888.

Angwin, D., Paroutis, S., \& Mitson, S. (2009). Connecting Up Strategy: Are Senior Strategy Directors a Missing Link? California Management Review, 51(3), 74-94.

Athanasopoulou A., \& Selsky, J.W. (2012). The social context of corporate social responsibility: Enriching research with multiple perspectives and multiple levels. Business \& Society, 54(3), 322-364.

Avetisyan, E. \& Ferrary, M. (2013). Dynamics of stakeholders' implications in the institutionalization of CSR field in France and in the United States'. Journal of Business Ethics, 115(1), 115-133.

Avetisyan, E. \& Hockerts, K. (forthcoming). Consolidation of ESG rating industry: Motivations and impacts. Business, Strategy and the Environment, DOI: 10.1002/bse. 1919

Balogun, J., Best, K., \& Lê, J. (2015). Selling the Object of Strategy: How Frontline Workers Realize Strategy through their Daily Work. Organization Studies, 36(10), 1285-1313. Balogun, J., Jarzabkowski, P., \& Seidl, D. (2007). Strategy as practice Perspective. In V. Ambrosini, M. Jenkins, \& N. Collier (Eds.), Advanced strategic management ( $2^{\text {nd }}$ ed.). Basingstoke: Palgrave Macmillan. 
Balogun, J., \& Johnson, G. (2005). From intended strategies to unintended outcomes: The impact of change recipient sensemaking. Organization Studies, 26(11), 1573-1601.

Barley, S.R. \& Tolbert, P.S. (1997). Institutionalization and structuration: Studying the links between action and institution. Organization Studies, 18(1), 93-117.

Battilana, J., Leca, B., \& Boxenbaum, E. (2009). How actors change institutions: Towards a theory of institutional entrepreneurship. The academy of management annals, 3(1), 65107.

Bhaskar, R. (1979). The possibility of naturalism: A philosophical critique of the contemporary human sciences. Brighton, Sussex: The Harvester Press.

Bourdieu, P. (1990). The logic of practice. Cambridge: Polity.

Bourdieu, P., \& Nice, R. (1977). Outline of a theory of practice. Vol. 16. Cambridge university press.

Bourque, N. \& Johnson, G. (2008). Strategy workshops and 'away days' as ritual. In G. P. Hodgkinson \& W. H. Starbuck (Eds.), Oxford Handbook of Organizational Decision Making. (pp. 552-564). Oxford: Oxford University Press.

Boutinot, A., \& Mangematin, V. (2013). Surfing on institutions: When temporary actors in organizational fields respond to institutional pressures. European Management Journal, 31(6), 626-641.

Boxenbaum, E., \& Jonsson, S. (2008). Isomorphism, diffusion and decoupling. In R. Greenwood, C. Oliver, K. Sahlin \& R. Suddaby (Eds.), Handbook of organizational institutionalism, (pp.78-98). New York: Sage

Brammer, S., Jackson, G., \& Matten, D. (2012). Corporate social responsibility and institutional theory: New perspectives on private governance. Socio-Economic Review, 10(1), 3-28. 
Brooks, S. (2005). Corporate social responsibility and strategic management: the prospects for converging discourses. Strategic Change, 14(7), 401-411.

Campbell, J.L. (2007). Why would corporations behave in socially responsible ways? An institutional theory of corporate social responsibility. Academy of Management Review, 32(3), 946-967.

Carter, C. (2013). The Age of Strategy: Strategy, Organizations and Society. Business History, 55(7), 1047-1057.

Carter, C., Clegg, S.R., \& Kornberger, M. (2008). So!apbox: Editorial essays: Strategy as practice. Strategic Organization, 6(1), 83-99.

Chandler, A. (1962). Strategy and structure: Chapters in the history of the industrial enterprise. Cambridge: M.I.T. Press.

Chatterji, A., Durand, R., Levine, D. I., \& Touboul, S. (2016). Do ratings of firms converge? Implications for managers, investors and strategy researchers. Strategic Management Journal, 37, 1597-1614

Chattopadhyay, P., Glick, W.H. \& Huber, G.P. (2001). Organizational actions in response to threats and opportunities. Academy of Management Journal, 44(5), 937-955.

Chia, R., \& MacKay, B. (2007). Post-processual challenges for the emerging strategy-aspractice perspective: Discovering strategy in the logic of practice. Human Relations, $60(1), 217-242$.

Clark, B.R. (1980). The "cooling out" function revisited. New Directions for Community Colleges, 32, 15-31.

Clegg, S., Kornberger, M. \& Rhodes, C. (2007). Business ethics as practice. British Journal of Management, 18(2), 107-122.

Coad, A.F., \& Glyptis, L.G. (2014). Structuration: A position-practice perspective and an illustrative study. Critical Perspectives on Accounting, 25(2), 142-161. 
Cohen, I.J. (1989). Structuration theory: Anthony Giddens and the constitution of social life. Basingstoke: Macmillan.

Coleman, J. S. (1991). Constructed organization: First principles. Journal of Law, Economics and Organization, 7-23.

Coleman, J.S. (1993). The design of organizations and the right to act. Sociological Forum, $8(4), 527-546$.

Dalton, M. (1959). Men who manage: Fusions of feeling and theory in administration. John Wiley \& Sons.

Déjean, F. (2005). L'Investissement Socialement Responsable-Etude du cas français' [Socially Responsable Investment - A Study of the French Case], Vuibert, Paris.

DiMaggio, P.J., \& Powell, W.W. (1983). The iron cage revisited: Institutional isomorphism and collective rationality in organizational fields. American Sociological Review, 48(2), 147-160.

DiMaggio, P.J., \& Powell, W.W. (1991). Introduction. In W.W. Powell \& P.J. DiMaggio (Eds.), The new institutionalism in organizational analysis (pp. 1-40). Vol. 17.

Chicago, IL: University of Chicago Press.

Doh, J. P., \& Guay, T. R. (2006). Corporate social responsibility, public policy, and NGO activism in Europe and the United States: An institutional-stakeholder perspective. Journal of Management Studies, 43, 47-73.

Durand, R. (2012). Advancing strategy and organization research in concert: Towards an integrated model?. Strategic Organization, 10(3), 297.

Emirbayer, M,. \& Mische, A. (1998). What is agency?. The American Journal of Sociology, 103(4), 962-1023. 
Foucault, M. (1982). I, Pierre Rivière, having slaughtered my mother, my sister, and my brother: a case of parricide in the 19th century. Lincoln Neb.: University of Nebraska Press.

Galbreath, J. (2013). ESG in focus: The Australian evidence. Journal of Business Ethics, $118(3), 529-541$.

Geser, H. (1992). Towards an interaction theory of organizational actors. Organization Studies, 13(3), 429-451.

Geser, H. (2002). Organizations as social actors. Sociology in Switzerland. Online publications.

Giddens, A. (1979). Central problems in social theory: Action, structure and contradiction in social analysis. London: Macmillan.

Giddens, A. (1984). The constitution of society: Introduction of the theory of structuration. Berkeley, CA: University of California Press.

Gjolberg, M. (2009). The origin of corporate social responsibility: Global forces or national legacies. Socio-Economic Review, 7, 605-637.

Gond, J.-P., Kang, N., \& Moon, J. (2011). The government of self-regulation: On the comparative dynamics of corporate social responsibility. Economy and Society, 40(4), $640-671$.

Gond, J.-P., \& Avetisyan, E. (2016). Making corporate social responsibility measurable, managing conflicting epistemic cultures: An history of Kinder, Lydenberg and Domini (KLD). Paper presented at (Im)possible Markets: 4th Interdisciplinary Market Workshop, St Andrews University, 2016.

Gouldner, A.W. (1954). Patterns of industrial bureaucracy. New York, NY: Free press.

Grant, R. M. (1991). The resource-based theory of competitive advantage: Implications for strategy formulation. California Management Review, 33(3), 114-135. 
Graves, S.B., \& Waddock, S.A. (1994). Institutional owners and corporate social performance. Academy of Management Journal, 37(4), 1034-1046.

Hannan, M.T., \& Freeman, J. (1984). Structural inertia and organizational change. American Sociological Review, 49(2), 149-164.

Hendry, J. \& Seidl, D. (2003). The structure and significance of strategic episodes: Social systems theory and the routine practices of strategic change. Journal of Management Studies, 40(1), 175-197.

Herepath, A. (2014). In the loop: A realist approach to structure and agency in the practice of strategy. Organization Studies, 35(6), 857-879.

Heugens, P. P., \& Lander, M. W. (2009). Structure! Agency!(and other quarrels): A metaanalysis of institutional theories of organization. Academy of Management Journal, $52(1), 61-85$.

Hoon, C. (2007). Committees as strategic practice: The role of strategic conversation in a public administration. Human Relations, 60(6), 921-952.

Howard-Grenville, J. A. (2007). Developing Issue-Selling Effectiveness over Time: Issue Selling as Resourcing. Organization Science, 18(4), 560-577.

Jackson, G., \& Apostolakou, A. (2010). Corporate social responsibility in western Europe: An institutional mirror or substitute?. Journal of Business Ethics, 94, 371-394.

Jarzabkowski, P. (2005). Strategy as practice: An activity based approach. London: Sage. Jarzabkowski, P. (2004). Strategy as practice: Recursiveness, adaptation and practices-in-use. Organization Studies, 25(4), 529-560.

Jarzabkowski, P., \& Seidl, D. (2008). The role of meetings in the social practice of strategy. Organization Studies, 29(11), 1391-1426.

Jarzabkowski, P., Balogun, J., \& Seidl, D. (2007). Strategizing: The challenges of a practice perspective. Human Relations, 60(1), 5-27. 
Jarzabkowski, P., \& Spee, A.P. (2009). Strategy-as-practice: A review and future directions for the field. International Journal of Management Reviews, 11(1), 69-95.

Jarzabkowski, P., \& Whittington, R. (2008). Hard to disagree, mostly. Strategic Organization, 6(1), 101-106.

Jarzabkowski, P., Smets, M., Bednarek, R., Burke, G., \& Spee, P. (2013). Institutional ambidexterity: Leveraging institutional complexity in practice. In M. Lounsbury \& E. Boxenbaum (Eds.), Institutional Logics in Action. Part B, Research in the Sociology of Organizations (pp. 37-61). Emerald Group Publishing Limited.

Jarzabkowski, P., Spee, A. P., \& Smets, M. (2013). Material artifacts: Practices for doing strategy with 'stuff’. European Management Journal, 31(1), 41-54.

Johnson, G., Melin, L., \& Whittington, R. (2003). Micro strategy and strategizing: Towards an activity-based view. Journal of Management Studies, 40(1), 3-22.

Kaplan, S. (2011). Strategy and PowerPoint: An Inquiry into the Epistemic Culture and Machinery of Strategy Making. Organization Science, 22(2), 320-346.

King, B.G., Felin, T., \& Whetten, D.A. (2010). Finding the organization in organizational theory: A meta-theory of the organization as a social actor. Organization Science, 21(1), $290-305$.

King, B.G., \& Walker, E.T. (2014). Winning hearts and minds: Field theory and the three dimensions of strategy. Strategic Organization, 12(2), 134-141.

Levitt, B., \& March, J. (1988). Organizational learning. Annual review of sociology, 319-340.

Mantere, S. (2005). Strategic practices as enablers and disablers of championing activity. Strategic Organization, 3(2), 157-184.

Mantere, S. (2008). Role Expectations and Middle Manager Strategic Agency. Journal of Management Studies, 45(2), 294-316. 
Matten, D., \& Moon, J. (2008). "Implicit" and "Explicit" CSR: A conceptual framework for a comparative understanding of corporate social responsibility. Academy of Management Review, 33(2), 404-424.

Marquis, C., Glynn, M. A., \& Davis, G. F. (2007). Community isomorphism and corporate social action. Academy of Management Review, 32(3), 925-945.

McAdam, D., \& Scott, W. R. (2005). Organizations and movements. In G. F. Davis, D.

McAdam, W. R. Scott \& M. N. Zald (Eds.), Social Movements and Organization Theory, (pp. 4-40).Cambridge University Press, New York.

Meyer, J.W., \& Rowan, B. (1977). Institutionalized organizations: Formal structure as myth and ceremony. American Journal of Sociology, 83(2), 340-363.

Mizruchi, M.S., \& Fein, L.C. (1999). The social construction of organizational knowledge: A study of the uses of coercive, mimetic, and normative isomorphism. Administrative Science Quarterly, 44, 653-683.

Okhuysen, G., \& Bonardi, J. (2011). Editors' comments: The challenges of building theory by combining lenses. Academy of Management Review, 36(1), 6-11.

Palmer, M., \& O’Kane, P. (2007). Strategy as practice: interactive governance spaces and the corporate strategies of retail transnationals. Journal of Economic Geography, 7(4), 515535.

Porter, M. (1980). Competitive strategy: Techniques for analyzing industries and competitors. New York: Free Press.

Powell, W.W., \& DiMaggio, P.J. (1991). The new institutionalism in organizational analysis. University of Chicago Press.

Richardson, B.J. (2009). Keeping ethical investment ethical: Regulatory issues for investing for sustainability. Journal of Business Ethics, 87(4), 555-572. 
Rouleau, L. (2005). Micro-Practices of Strategic Sensemaking and Sensegiving: How Middle Managers Interpret and Sell Change Every Day. Journal of Management Studies, 42(7), 1413-1441.

Scalet, S., \& Kelly, T.F. (2010). CSR rating agencies: What is their global impact?. Journal of Business Ethics, 94(1), 69-88.

Scherer, A.G., \& Palazzo, G. (2011). The new political role of business in a globalized world: A review of a new perspective on CSR and its implications for the firm, governance, and democracy. Journal of Management Studies, 48(4), 899-931.

Scott, W.R. (2008). Institutions and organizations: Ideas and interests. London: Sage.

Scott, R.W., \& Meyer, J.W. (1983). The organization of societal sectors. In J.W. Meyer \& W.

R. Scott (Eds.), Organizational Environments: Ritual and Rationality (pp. 129-153). Beverly Hills.

Seidl, D., \& Whittington, R. (2014). Enlarging the strategy-as-practice research agenda: Towards taller and flatter ontologies. Organization Studies, 35(10), 1407-1421.

Selznick, P. (1949). TVA and the Grass Roots: A Study in the Sociology of Formal Organization. Vol. 3, Univ of California Press.

Sharfman, M. (1996). The construct validity of the Kinder, Lydenberg and Domini social performance ratings data. Journal of Business Ethics, 15(3), 287-296.

Sharp, Z., \& Zaidman, N. (2010). Strategization of CSR. Journal of Business Ethics, 93(1), 51-71.

Slager, R., \& Chapple, W. (2015). Carrot and stick? The role of financial market intermediaries in corporate social responsibility. Business \& Society. 0007650315575291 
Slager, R., Gond, J.-P., \& Moon, J. (2012). Standardization as institutional work: the regulatory power of a responsible investment standard. Organization Studies, 33, 763790.

Smets, M., \& Jarzabkowski, P. (2013). Reconstructing institutional complexity in practice: A relational model of institutional work and complexity. Human Relations, 66(10), 1279 1309.

Smets, M., Jarzabkowski, P., Burke, G., \& Spee, P. (2015). Reinsurance trading in Lloyd's of London: Balancing conflicting-yet-complementary logics in practice, Academy of Management Journal, 58(3), 932-970.

Smets, M., Morris, T., \& Greenwood, R. (2012). From practice to field: A multilevel model of practice-driven institutional change. Academy of Management Journal, 55(4), 877904.

Stål, H. I., Bonnedahl, K. J., \& Eriksson, J. (2014). The challenge of introducing low-carbon industrial practices: Institutional entrepreneurship in the agri-food sector. European Management Journal, 32(2), 203-215.

Stones, R. (2005). Structuration theory. Basingstoke: Palgrave Macmillan.

Stones, R., \& Tangsupvattana, A. (2012). Social theory, current affairs, and Thailand's political turmoil: Seeing beyond reds vs. Yellows. Journal of Political Power, 5(2), $217-238$.

Sturdy, A., Schwartz, M., \& Spicer, A. (2006). Guess who's coming to dinner? Structures and uses of liminality in strategic management consultancy. Human Relations, 59(7), 929960.

Suddaby, R., Seidl, D., \& Lê, J.K. (2013). Strategy-as-practice meets neo-institutional theory. Strategic Organization, 11(3), 329-344. 
Suominen, K. \& Mantere, S. (2010). Consuming Strategy: The art and practice of managers' everyday strategy usage. In J. A. C. Baum \& J. Lampel (Eds.), The Globalization of Strategy Research: Advances in Strategic Management (pp. 211-245). Bingley, UK: Emerald Group Publishing Ltd.

Tempel, A., \& Walgenbach, P. (2007). Global standardization of organizational forms and management practices? What new institutionalism and the business-systems approach can learn from each other. Journal of Management Studies, 44(1), 1-24.

Vaara, E., \& Whittington, R. (2012). Strategy-as-Practice: Taking social practices seriously. The Academy of Management Annals, 6(1), 285-336.

Vergne, J.-P., \& Durand, R. (2010). The missing link between the theory and empirics of path dependence: Conceptual clarification, testability issue, and methodological implications. Journal of Management Studies, 47(4), 736-759.

Waddock, S. (2003). Myths and realities of social investing. Organization and Environment, 16(3), 369-380.

Waddock, S. \& Graves, S.B. (1997). The Corporate social performance-financial performance link. Strategic Management Journal, 18(4), 303-319.

Whittington, R. (1992). Putting giddens into action: Social systems and managerial agency. Journal of Management Studies, 29(6), 693-712.

Whittington, R. (2003). The work of strategizing and organizing: For a practice perspective. Strategic Organization, 1(1), 117-125.

Whittington, R. \& Melin, L. (2003). The Challenges of Organizing/Strategizing. In A. M. Pettigrew et al. (Eds.), Innovative forms of organizing: International perspective (pp. 34-49). London: Sage.

Windsor, D. (2006). Corporate social responsibility: Three key approaches. Journal of Management Studies, 43(1), 93-114. 
Zavyalova, A., Pfarrer, M. D., Reger, R. K., \& Shapiro, D. L. (2012). Managing the message: The effects of firm actions and industry spillovers on media coverage following wrongdoing. Academy of Management Journal, 55(5), 1079-1101. 